\title{
Phosphorus uptake kinetics and nitrogen fractions in maize grown in nutrient solutions
}

\section{Cinética de absorção de fósforo e frações nitrogenadas em milho cultivado em solução nutritiva}

\author{
Leandro Martins Ferreira ${ }^{1 *}$; Rafael Passos Rangel ${ }^{2}$; \\ Orlando Carlos Huertas Tavares ${ }^{3}$; Leandro Azevedo Santos ${ }^{4}$; \\ Sonia Regina de Souza ${ }^{5}$; Manlio Silvestre Fernandes ${ }^{6}$
}

\begin{abstract}
The analysis of ion uptake kinetics is the key experimental procedure for determining the uptake efficiency of different species and varieties. The principal goal of this study was to evaluate phosphorus (P) uptake and its effect on nitrogen $(\mathrm{N})$ metabolism in two maize varieties (Sol da Manhã and Eldorado) and one improved maize cultivar (AG 122®) exposed to a resupply of 10 or $100 \mu \mathrm{M}$ of P following a period of $\mathrm{P}$ deprivation. The experiment was based on a completely randomized design with four replicates, with treatments arranged in a $3 \times 2$ factorial scheme consisting of three genotypes and two $\mathrm{P}$ doses. The treatments were applied at 16 days after germination (DAG), and samples of nutrient solution were collected over time to estimate the kinetics of $\mathrm{P}$ uptake $\left(\mathrm{V}_{\max }, \mathrm{K}_{\mathrm{M}}\right.$ and $\left.\mathrm{C}_{\min }\right)$. At the end of the experiment, a portion of the total fresh weight was stored to determine $\mathrm{N}$ fractions and soluble sugars. Under the experimental conditions, the AG 122® cultivar showed the lowest $\mathrm{K}_{\mathrm{M}}$ and $\mathrm{C}_{\min }$ values for both $\mathrm{P}$ doses, indicating a higher uptake efficiency for these plants. In contrast, the Eldorado and Sol da Manhã varieties showed the highest $\mathrm{V}_{\max }$ values. An absence of $\mathrm{P}$ from the nutrient solution for one day, followed by the addition of $10 \mu \mathrm{M}$ of $\mathrm{P}$ for the same period, did not result in alterations in $\mathrm{N}$ metabolism in any of the genotypes. However, it was observed that the Sol da Manhã and Eldorado varieties concentrated their $\mathrm{NO}_{3}^{-}-\mathrm{N}$ metabolism in their roots, whereas the $A G 122 \AA$ cultivar concentrated its $\mathrm{NO}_{3}^{-}-\mathrm{N}$ metabolism in its shoots.
\end{abstract}

Key words: Zea mays L, nitrate, ammonium, amino-N, soluble sugars

\section{Resumo}

A análise das variáveis cinéticas de absorção de íons é o principal procedimento experimental para a diferenciação da eficiência de absorção entre espécies e variedades. Baseado nisso, o objetivo desse trabalho foi avaliar a absorção de fósforo $(\mathrm{P})$ e o seu efeito no metabolismo de nitrogênio $(\mathrm{N})$ em variedades (Sol da Manhã e Eldorado) e cultivar (AG 122®) de milho (Zea mays L.) submetidos ao ressuprimento com 10 e $100 \mu \mathrm{M}$ de P. O delineamento experimental utilizado foi inteiramente casualizado, com quatro repetições. Os tratamentos foram dispostos em esquema fatorial $3 \times 2$, sendo três genótipos e dois níveis de P. Aos 16 dias após a germinação (DAG) foram aplicados os tratamentos e procedeu-se a

\footnotetext{
${ }^{1}$ Eng $^{\mathrm{o}}$ Agr $^{\circ}$, Discente do Curso de Doutorado em Ciência do Solo, CPGA-CS, Universidade Federal Rural do Rio de Janeiro, UFRRJ, Seropédica, RJ, Brasil. E-mail: leandromartins@ufrrj.br

${ }^{2}$ Eng $^{\text {O Agr }}{ }^{\circ}$, Discente do Curso de Mestrado em Agronomia, CPGA-CS, UFRRJ, Seropédica, RJ, Brasil. E-mail: passos@ufrrj.br

${ }^{3}$ Eng $^{\circ}$ Agr $^{\circ}$, Discente do Curso de Doutorado em Agronomia, CPGF, UFRRJ, Seropédica, RJ, Brasil. E-mail: ochtavares@gmail.com

${ }^{4}$ Eng $^{\mathrm{o}}$ Agr $^{\mathrm{o}}$, Prof. Adjunto II, Dept ${ }^{\mathrm{O}}$ de Solos, UFRRJ, Seropédica, RJ, Brasil. E-mail: azevedo@ufrrj.br

${ }^{5}$ Eng $^{\mathrm{a}}$ Agr $^{\mathrm{a}}$, Prof ${ }^{\mathrm{a}}$ Associada IV, Dept ${ }^{\mathrm{o}}$ de Química, UFRRJ, Seropédica, RJ, Brasil. E-mail: soniabq@ufrrj.br

${ }^{6}$ Eng $^{\text {o }}$ Agr $^{\circ}$, Prof. Emérito, Dept ${ }^{\circ}$ de Solos, UFRRJ, Seropédica, RJ, Brasil. E-mail: manlio@ufrrj.br

${ }^{*}$ Author for correspondence
} 
coleta da solução nutritiva ao longo do tempo para estimar as variáveis cinéticas de absorção de $\mathrm{P}\left(\mathrm{V}_{\text {máx}}\right.$, $\mathrm{K}_{\mathrm{M}}$ e $\mathrm{C}_{\text {min }}$ ) e na coleta final parte da massa fresca total foi armazenada para determinação das frações

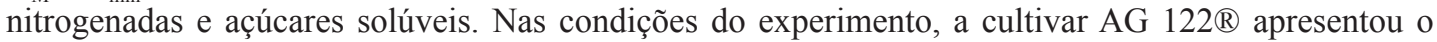
menor valor de $\mathrm{K}_{\mathrm{M}}$ e $\mathrm{C}_{\text {min }}$ nas duas doses de $\mathrm{P}$, o que indica uma maior eficiência de absorção por essas plantas, enquanto as variedades Eldorado e Sol da Manhã apresentaram os maiores valores de $\mathrm{V}_{\text {máx }}$. $\mathrm{A}$ omissão de $\mathrm{P}$ da solução nutritiva por um dia, seguido da adição de uma dose de $10 \mu \mathrm{M}$ desse nutriente por igual período não provocou alterações no metabolismo de $\mathrm{N}$ entre os genótipos estudados, no entanto, foi observado que as variedades Sol da manhã e Eldorado têm preferência para o metabolismo de $\mathrm{N}_{-} \mathrm{NO}_{3}^{-}$na raiz quando comparadas a cultivar $\mathrm{AG} 122 \AA$ que o faz preferencialmente na parte aérea.

Palavras-chave: Zea mays L., nitrato, amônio, N-amino, açúcares solúveis

\section{Introduction}

Maize is a plant of high nutritional quality. It is widely used for food and as a feedstock in industry. The world production of maize in 2012 was 845 million tons. The largest producers in 2012 were the United States (36.2\% of world production), China (22.1\%) and Brazil (7.0\%) (NCGA, 2012).

Significant increases in maize production have been achieved from the incorporation of new areas in the productive sector and especially from increases in productivity in areas that are already cultivated. However, most Brazilian soils are highly weathered, with high acidity, toxic levels of aluminum and low levels of nutrients, especially P (PARENTONI; MENDES; GUIMARÃES, 2011). Most of these soils do not provide sufficient $\mathrm{P}$ for normal plant development. Therefore, the low availability of this nutrient represents a major constraint on plant growth (SHEN et al., 2006).

$\mathrm{P}$ uptake occurs actively against its electrochemical potential gradient. This process is a secondary form of active transport $\left(\mathrm{H}_{2} \mathrm{PO}_{4}^{-} / \mathrm{H}^{+}\right)$, energized by protons $\left(\mathrm{H}^{+}\right)$generated by the driving plasma membrane ATPases (RAGHOTHAMA, 2000).Kinetics studies of $P$ uptake have demonstrated that both low and high-affinity transporters for phosphate can be found in plants: a low-affinity system with $\mathrm{K}_{\mathrm{M}}$ between 50.0 and 300.0 $\mu \mathrm{M}$ and a high-affinity system with $\mathrm{K}_{\mathrm{M}}$ between 2.0 and $10.0 \mu \mathrm{M}$. Therefore, given the usual phosphate concentrations in cultivated soils $(1.0$ to $10.0 \mu \mathrm{M})$, the high-affinity uptake system mediates the uptake of P (VANCE; UHDE-STONE; ALLEN, 2003).
In breeding programs, the efficiency of genotypes and their ability to respond to nutrient application are important for the development of cultivars with improved nutrient use efficiency. The evaluation of genotypes in environments varying in the availability of a given nutrient has been used to characterize the acquisition and /or efficiency of use of nutrients (PATERNIANI, 1993; PARENTONI et al., 2010).

Differences in the patterns of nutrient uptake between species and varieties can be identified based on information about the variables that characterize the kinetics of ion uptake. Plants with a greater capacity for $\mathrm{P}$ uptake and use are more efficient and facilitate a reduction in the use of fertilizers as well as adaptation to environments with constraints on the nutrient supply, thus offering gains in productivity without increasing production costs.

Therefore, it is necessary to study $\mathrm{P}$ uptake mechanisms to aid in the development of future breeding programs that aim to produce plants having a greater $\mathrm{P}$ use efficiency. Based on this perspective, the current study aimed to determine the variables associated with the kinetics of $\mathrm{P}$ uptake and the changes in $\mathrm{N}$ metabolism in the Sol da Manhã and Eldorado varieties and the AG $122 \AA$ cultivar exposed to $\mathrm{P}$ concentrations of $10 \mu \mathrm{M}$ and $100 \mu \mathrm{M}$.

\section{Materials and Methods}

The experiment was performed in a climate chamber (day/night rhythm, $14 / 10 \mathrm{~h} ; 28 / 24^{\circ} \mathrm{C}$; light 
intensity, $260 \mu \mathrm{mol} \mathrm{m}^{-2} \mathrm{~s}^{-1}$; relative humidity, 80\%). The varieties Sol da Manhã and Eldorado, which are adapted to low soil fertility, and a simple hybrid (AG 122) from AgroceresÒ were used.

Maize seeds were first sterilized in a solution of sodium hypochlorite ( $2 \%$ ) for 10 minutes, followed by repeated washings with distilled water. The seeds were then placed on gauze in $1.7 \mathrm{~L}$ pots and transferred to a climate chamber. Five days after germination (DAG), the seedlings were transferred to Hoagland and Arnon nutritive solution (1950) with $1 / 2$ ionic strength (IS) modified with $2.0 \mathrm{mM}$ of $\mathrm{N}\left(1.50 \mathrm{mM}\right.$ of $\mathrm{KNO}_{3}^{-}$and $\left.0.25 \mathrm{mM}\left(\mathrm{NH}_{4}^{+}\right)_{2} \mathrm{SO}_{4}\right)$; $250.0 \mu \mathrm{M}$ of $\mathrm{KH}_{2} \mathrm{PO}_{4} ; 2.50 \mathrm{mM} \mathrm{CaSO}{ }_{4} \cdot 2 \mathrm{H}_{2} \mathrm{O}$; $1.25 \mathrm{mM} \mathrm{K}_{2} \mathrm{SO}_{4} ; 1.0 \mathrm{mM} \mathrm{MgSO}{ }_{4} .7 \mathrm{H}_{2} \mathrm{O} ; 40.0$ $\mu \mathrm{M}$ Fe-EDDHMA; $4.50 \mu \mathrm{M} \quad \mathrm{MnCl}_{2} ; 0.50 \mu \mathrm{M}$ $\left(\mathrm{NH}_{4}\right)_{6} \mathrm{Mo}_{7} \mathrm{O}_{24} ; 23.0 \mu \mathrm{M} \mathrm{H}_{3} \mathrm{BO}_{3} ; 0.50 \mu \mathrm{M} \mathrm{ZnSO}$; and $0.15 \mu \mathrm{M} \mathrm{CuSO}_{4}$. The $\mathrm{pH}$ was maintained at 5.7. The nutrient solution was changed every three days, and the pots were equipped with an intermittent aeration system with cycles of 15 minutes hour 1. At $15 \mathrm{DAG}$, the plants were transferred to a nutrient solution without $\mathrm{P}$ for one day to increase the capacity for nutrient uptake in the plants that would be exposed to the treatments. At 16 DAG, the treatments were applied. The treatments consisted of $\mathrm{P}$ at concentrations of $10 \mu \mathrm{M}$ or $100 \mu \mathrm{M}$ of $\mathrm{P}$. Samples of nutrient solution were collected at intervals of one hour during the first ten hours and at $24 \mathrm{~h}$ and $25 \mathrm{~h}$ (Figure 1).

Figure 1. Experimental scheme in the climate chamber. Application of the nutrient solution in the Sol da Manhã (SM) and Eldorado varieties and the AG $122 ®$ cultivar. Harvest at 16 DAG to evaluate the kinetic parameters of P uptake and soluble fractions in fresh material.

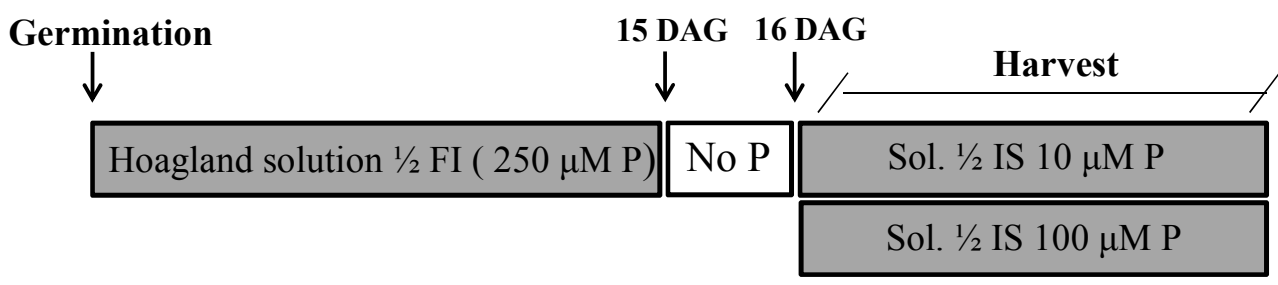

Source: Elaboration of the authors.

At the end of the experiments, roots were harvested to obtain the fresh weight and calculate the variables characterizing the kinetics of the uptake of $\mathrm{P}\left(\mathrm{V}_{\max }\right.$ and $\left.\mathrm{K}_{\mathrm{M}}\right)$ in each treatment based on the decrease in the concentration of ions in the nutrient solution over time according to the method described by Claassen and Barber (1974). The curve fitting and depletion calculations were performed by employing the mathematical graphing process proposed by Ruiz and Fernandes Filho (1992) and Cometti et al. (2006) with Cineticawin 1.0 software (UFV). The P present in the solution was determined according to Braga and Defelipo (1974).

$\mathrm{C}_{\min }$ was estimated by determining the $\mathrm{P}$ remaining in the nutrient solution in the treatment with $10 \mu \mathrm{M}$ in the final samples at $24 \mathrm{~h}$ and $25 \mathrm{~h}$. The $\mathrm{C}_{\text {min }}$ of plants exposed to resupply with $100 \mu \mathrm{M}$ of $\mathrm{P}$ was not determined because the concentration at which ion uptake halts was not reached.

After the plants were harvested, one gram of fresh weight from the shoots or the roots was homogenized in $80 \%$ ethanol following chloroform partition (FERNANDES, 1984) The soluble fraction obtained was used to determine the free amino-N levels (YEMM; COCKING, 1955), $\mathrm{NO}_{3}^{-}$ -N (CATALDO et al., 1975), $\mathrm{NH}_{4}^{+}$-N (FELKER, 1977) and soluble sugars (YEMM; WILLIS, 1957).

The experiment followed a completely randomized factorial design with three genotypes 
and two levels of $\mathrm{P}$ with four replicates and four plants per pot. The mathematical model for the experimental results was given by the equation $Y i j=\mu+\mathrm{Ti}+\mathrm{Tj}+\mathrm{Ti} * \mathrm{Tj}+$ eij. The results were submitted to an analysis of variance and an F test, and the means were compared using a Tukey test at $\mathrm{p} \leq 0.05$ (PIMENTEL-GOMES, 2000).

\section{Results and Discussion}

$P$ is an extremely scarce nutrient in most cultivated areas in Brazil, and its concentration is generally in the micromolar range (ALVES et al., 2002). Consequently, management strategies designed to overcome this low availability require both proper management (fertilization and management for increasing organic matter) and the use of genotypes that are better adapted to this ecosystem (VENEKLAAS et al., 2012). The noteworthy adaptive mechanisms used by plants to increase P uptake include changes in architecture and root growth, modification of the rhizosphere via exudation of organic acids by the roots and increases in the rate of $\mathrm{P}$ uptake resulting from increases in the expression of high-affinity transporters (MUCHHAL; RAGHOTHAMA, 1999).

The Eldorado variety and the AG $122 \AA$ cultivar showed a higher weight of shoots and roots under the treatments with $10 \mu \mathrm{M}$ and $100 \mu \mathrm{M}$ of $\mathrm{P}$. However, a higher root weight was observed for these plants in the low-P treatment (Table 1). Changes in architecture and root growth are considered mechanisms that increase the efficiency of P uptake because the increase in the volume of soil explored by the roots can provide a higher uptake capacity, especially in oxidic soils with a high capacity for $\mathrm{P}$ fixation (YAN et al., 2001).

Table 1. Fresh weight of shoots and roots in the Sol da Manhã and Eldorado varieties and the AG $122 ®$ cultivar exposed to $10 \mu \mathrm{M}$ and $100 \mu \mathrm{M}$ of $\mathrm{P}$ at 16 days after germination.

\begin{tabular}{ccccccc}
\hline \multirow{2}{*}{ Genotypes } & \multicolumn{2}{c}{ Shoots $(\mathrm{g})$} & & \multicolumn{2}{c}{ Roots $(\mathrm{g})$} \\
\cline { 2 - 3 } \cline { 5 - 6 } \cline { 5 - 6 } & $10 \mu \mathrm{M}$ & $100 \mu \mathrm{M}$ & & $10 \mu \mathrm{M}$ & $100 \mu \mathrm{M}$ \\
\hline Sol da Manhã & $17.02 \mathrm{bA}$ & $18.66 \mathrm{bA}$ & & $6.96 \mathrm{bA}$ & $6.12 \mathrm{bA}$ \\
Eldorado & $23.02 \mathrm{aA}$ & $17.69 \mathrm{bB}$ & & $8.44 \mathrm{aA}$ & $6.93 \mathrm{abB}$ \\
AG 122 & $23.79 \mathrm{aA}$ & $24.46 \mathrm{aA}$ & & $8.58 \mathrm{aA}$ & $7.58 \mathrm{aB}$ \\
\hline C.V.\% & 4.56 & 6.20 & & 5.32 & 6.34 \\
\hline
\end{tabular}

Averages followed by the same lowercase letter in the same column or the same uppercase letter in the same row do not differ statistically (Tukey test, $\mathrm{p} \leq 0.01$ ).

Source: Elaboration of the authors.

Schoninger, Gatiboni and Ernani (2013), studying $\mathrm{P}$ uptake in soybean (Glycine $\max \mathrm{L}$.) and cover crops of the Cerrado (brachiaria, millet and sorghum), found greater root growth in plants of millet (Pennisetum glaucum L.) and brachiaria (Brachiaria brizantha Hochst Stapf) in a treatment without $\mathrm{P}$ supply. This result indicates that under conditions of limited P, most of this element is metabolized by the roots, resulting in the increased growth of this structure.
In addition to the influence of nutrients on the morphological attributes of the plant, the nutrient uptake efficiency is influenced by several kinetic variables: the maximum velocity $\left(\mathrm{V}_{\max }\right)$ - the maximum transport speed of a nutrient when all sites of transport are loaded; the Michaelis-Menten constant $\left(\mathrm{K}_{\mathrm{M}}\right)$ - the carrier affinity for the nutrients to be transported; and $\mathrm{C}_{\min }$ - the nutrient concentration in the solution when the liquid influx is equal to zero (MARSCHNER, 1995). P uptake by plants can be performed by a high-affinity or low affinity transport 
system according to the nutrient concentration in the external medium (FERNANDES; SOUZA, 2006).

The AG $122 \AA$ cultivar showed the lowest $\mathrm{K}_{\mathrm{M}}$ value of the three tested genotypes for both the $10 \mu \mathrm{M}$ and the $100 \mu \mathrm{M}$, treatments, indicating its higher affinity at both $\mathrm{P}$ concentrations (Table 2). According to Horn et al. (2006), lower $\mathrm{K}_{\mathrm{M}}$ values are always desirable when plants with a higher $\mathrm{P}$ uptake efficiency are selected. The P concentration in the vacuole and the concentration of inorganic $\mathrm{P}$ in the cell serve to activate gene regulation mechanisms in high- and low-affinity transporters (RAGHOTHAMA, 1999). The period of $\mathrm{P}$ deprivation before the exposure to the treatments may have altered the intracellular status of this nutrient, resulting in an increased expression of high- and low-affinity transporters, especially in the AG $122 \AA$ cultivar.

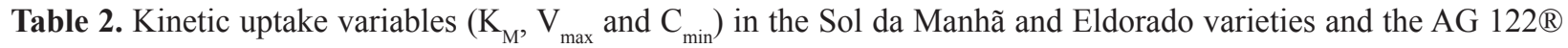
cultivar exposed to $10 \mu \mathrm{M}$ and $100 \mu \mathrm{M}$ of $\mathrm{P}$ at 16 days after germination.

\begin{tabular}{|c|c|c|c|c|c|}
\hline \multirow{2}{*}{ Genotypes } & \multicolumn{2}{|c|}{$\mathrm{K}_{\mathrm{M}}(\mu \mathrm{mol} \mathrm{L}-1)$} & \multicolumn{2}{|c|}{$\mathrm{V}_{\max }\left(\mu \mathrm{mol} \mathrm{g}{ }^{-1} \mathrm{~h}^{-1}\right)$} & $\left.\mathrm{C}_{\min }(\mu \mathrm{mol} \mathrm{L})^{-1}\right)$ \\
\hline & $10 \mu \mathrm{M}$ & $100 \mu \mathrm{M}$ & $10 \mu \mathrm{M}$ & $100 \mu \mathrm{M}$ & $10 \mu \mathrm{M}$ \\
\hline Sol da Manhã & $7.36 \mathrm{a}$ & $90.95 a$ & $1.67 \mathrm{a}$ & $86.23 a$ & $6.69 \mathrm{a}$ \\
\hline Eldorado & $7.12 \mathrm{a}$ & $87.67 \mathrm{a}$ & $1.36 \mathrm{ab}$ & $53.18 \mathrm{ab}$ & $6.50 \mathrm{a}$ \\
\hline AG 122 & $5.29 \mathrm{~b}$ & $59.43 b$ & $1.11 \mathrm{~b}$ & $20.27 b$ & $4.61 \mathrm{~b}$ \\
\hline C.V.\% & 8.4 & 12.5 & 7.2 & 14.4 & 13.34 \\
\hline
\end{tabular}

Averages followed by the same lowercase letter in the same column do not differ statistically (Tukey test, $\mathrm{p} \leq 0.05$ ).

Source: Elaboration of the authors.

$\mathrm{C}_{\text {min }}$ values of 6.69, 6.50 and $4.61 \mu \mathrm{mol} \mathrm{L}{ }^{-1}$ were found for Sol da Manhã, Eldorado and AG 122®, respectively. The finding of the lowest $\mathrm{C}_{\min }$ value in AG $122 \AA$ may be related to its low $\mathrm{K}_{\mathrm{M}}$. However, it is known that the $\mathrm{C}_{\text {min }}$ values change if plants are subjected to different conditions (MARSCHNER, 1995).

The lower affinity for P shown by Sol da Manhã and Eldorado i.e., the higher $\mathrm{K}_{\mathrm{M}}$ value found in the treatments with $10 \mu \mathrm{M}$ and $100 \mu \mathrm{M}$ of $\mathrm{P}$, does not indicate that these varieties are not efficient at $\mathrm{P}$ uptake at low concentrations. Other mechanisms may also be involved in efficiency, such as exudation of organic acids by the roots and changes in root architecture, i.e., an increased number of lateral roots and hair roots (LIU et al., 1998).

Sol da Manhã and Eldorado showed a higher $\mathrm{V}_{\max }$ than did the AG122® cultivar in both treatments, especially in the treatment with $100 \mu \mathrm{M}$ of P. A higher $\mathrm{V}_{\max }$ corresponds to a larger number of transport sites, indicating that these varieties naturally present a higher uptake capacity, even with a low affinity
$\left(\mathrm{K}_{\mathrm{M}}\right)$. Note that a higher $\mathrm{V}_{\max }$ does not necessarily result in a lower $\mathrm{K}_{\mathrm{M}}$ because these variables are independent in the uptake process, as observed by Stefanutti (1997) and Moreira et al. (2003a). The use of mycorrhizal fungi in symbiosis with these varieties may also result in changes in the kinetic variables, particularly in reducing the $\mathrm{K}_{\mathrm{M}}$ and $\mathrm{C}_{\text {min }}$ values (FAQUIN; MALAVOLTA; MURAOKA, 1990). It has been reported that the $P$ transporters of mycorrhizal fungi have a lower $\mathrm{K}_{\mathrm{M}}$ value than the $\mathrm{P}$ transporters of plants (CARDOSO et al., 2010).

Depletion curves were obtained by analyzing the $\mathrm{P}$ concentration in the nutrient solution over time (h). Note that the depletion curves have no direct effect on the kinetic variables because the depletion curves do not reflect the root biomass and other variables used in the calculations.

The depletion curve for the treatment with 10 $\mu \mathrm{M}$ of $\mathrm{P}$ indicates that after $10 \mathrm{~h}$ of exposure, the AG $122 \circledR$ cultivar showed a higher uptake rate than those of the other two studied varieties (Figure 2a). The same behavior was observed in the treatment 
with $100 \mu \mathrm{M}$ of $\mathrm{P}$, where a separation between the plants occurred at $7 \mathrm{~h}$, followed by an increased uptake rate in $A G 122 \AA$ (Figure $2 b$ ). The high rate of P uptake observed in the AG $122 \AA$ depletion curve is a result of increased biomass due to more vigorous growth during the early stages (Table 1). Therefore, this finding is not related to $\mathrm{V}_{\max }$ (Table 2). According to Stefanutti (1997) and Moreira et al. (2003b), nutrient uptake is controlled primarily by genetic and environmental factors, and the differences observed in the current study may be a result of the use of different genotypes.

At the end of the kinetic trial, the plants were harvested to determine the amount of $\mathrm{P}$ accumulated in the tissues. As expected, due to its lower $\mathrm{K}_{\mathrm{M}}$ and $\mathrm{C}_{\min }$ values (Table 2), cultivar AG 122® showed the highest $\mathrm{P}$ concentration in plant tissue in both treatments (Table 3 ). The finding that the highest $\mathrm{P}$ concentration (3.27 $\mathrm{mg} \mathrm{g}^{-1}$ ) occurred in cultivar AG $122 \AA$ under the treatment with $10 \mu \mathrm{M}$ P suggests a greater capacity for $\mathrm{P}$ uptake by this genotype (Table 3) (VENEKLAAS et al., 2012)
Note that the responses of the genotypes could differ under conditions in which nutrients were highly limiting, as the Sol da Manhã and Eldorado varieties were bred to grow in low-fertility soils. In these soils, the $\mathrm{P}$ concentrations often vary between $1.0 \mu \mathrm{M}$ and $10 \mu \mathrm{M}$ (VANCE; UHDESTONE; ALLEN, 2003). Additionally, as the period of $\mathrm{P}$ deprivation was only $24 \mathrm{~h}$, it might not have produced a sufficiently severe P deficiency to allow the development of adaptive mechanisms in the Sol da Manhã and Eldorado varieties that were capable of exceeding the response capacity of the AG $122 \AA$ cultivar.

Increases in the $\mathrm{P}$ supply to the plants can promote additions to the total $\mathrm{N}$ content and enhance nutrient use efficiency, whereas $\mathrm{N}$ assimilation is impaired if the P supply is limited (JESCHKE et al. 1997). The major effects on $\mathrm{N}$ assimilation resulting from a low $\mathrm{P}$ supply include a decrease in the $\mathrm{NO}_{3}{ }^{-}$uptake and translocation and accumulation of amino- $\mathrm{N}$ in leaves and roots resulting from the synthesis or degradation of proteins (ISRAEL; RUFTY, 1988; RUFTY; MACKOWN; ISRAEL, 1990).

Figure 2. P depletion vs. time in the nutrient solution in the Sol da Manhã (SM) and Eldorado varieties and the AG $122 ®$ cultivar exposed to $10 \mu \mathrm{M}$ and $100 \mu \mathrm{M}$ of $\mathrm{P}$ at 16 days after germination. Bars represent the standard error for four replicates.
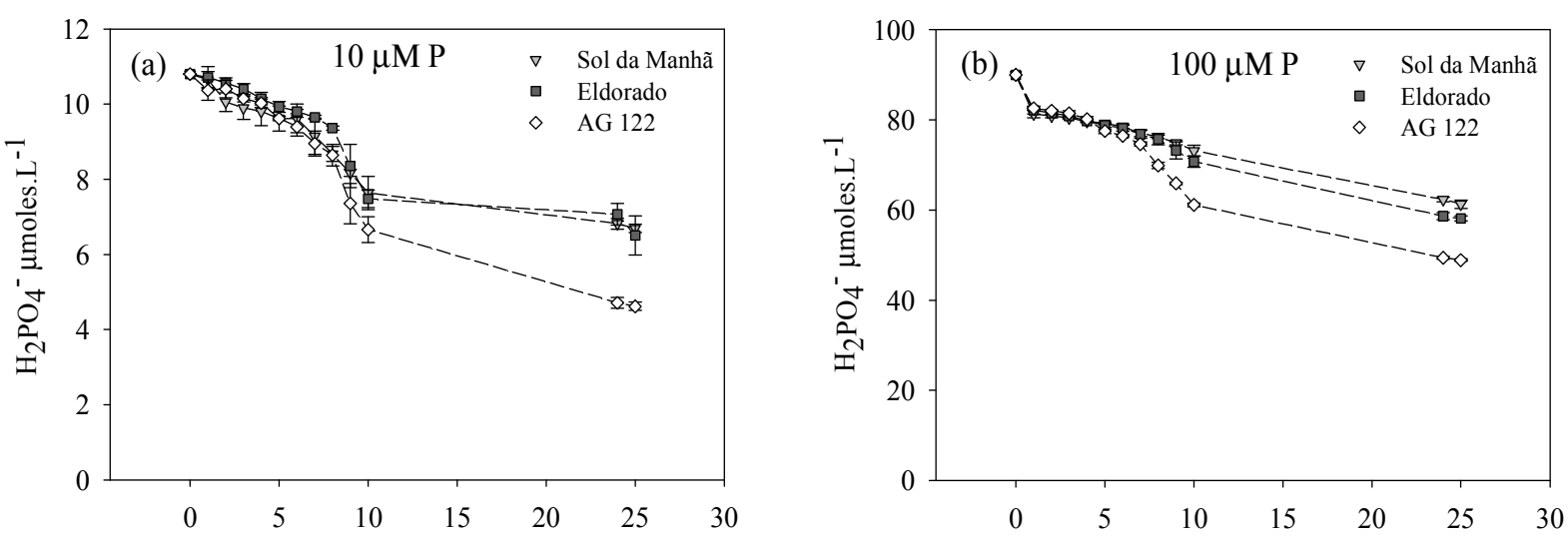

Source: Elaboration of the authors. 
Table 3. Phosphorus content per unit fresh weight in the Sol da Manhã and Eldorado varieties and the AG $122 ®$ cultivar exposed to $10 \mu \mathrm{M}$ and $100 \mu \mathrm{M}$ of $\mathrm{P}$ at 16 days after germination.

\begin{tabular}{|c|c|c|c|c|}
\hline \multicolumn{5}{|c|}{ Phosphorus content in dry weight $\left(\mathrm{mg} \cdot \mathrm{g}^{-1}\right)$} \\
\hline \multirow{2}{*}{ Genotypes } & \multicolumn{2}{|c|}{ Shoots } & \multicolumn{2}{|c|}{ Roots } \\
\hline & $10 \mu \mathrm{M}$ & $100 \mu \mathrm{M}$ & $10 \mu \mathrm{M}$ & $100 \mu \mathrm{M}$ \\
\hline Sol da Manhã & $2.22 b$ & $1.99 \mathrm{~b}$ & $1.71 \mathrm{~b}$ & $1.44 b$ \\
\hline Eldorado & $2.26 \mathrm{~b}$ & $2.05 \mathrm{~b}$ & $1.82 \mathrm{~b}$ & $1.65 b$ \\
\hline AG 122 & $2.51 \mathrm{a}$ & $2.32 \mathrm{a}$ & $3.27 \mathrm{a}$ & $2.84 \mathrm{a}$ \\
\hline C.V.\% & \multicolumn{2}{|c|}{8.55} & \multicolumn{2}{|c|}{10.42} \\
\hline
\end{tabular}

Averages followed by the same lowercase letter in the same column do not differ statistically (Tukey test, $\mathrm{p} \leq 0.05$ ).

Source: Elaboration of the authors.

In general, $\mathrm{NO}_{3}^{-}$uptake was not affected by the treatment with $10 \mu \mathrm{M}$ of $\mathrm{P}$, suggesting that this phosphorus concentration did not correspond to a limiting condition for all genotypes studied (Figure 3). The AG $122 \AA$ cultivar showed a higher $\mathrm{NO}_{3}^{-}$ concentration in the shoots than the Sol da Manhã and Eldorado varieties when exposed to $10 \mu \mathrm{M}$ of $\mathrm{P}$, however, the opposite result was observed for the roots, with a lower $\mathrm{NO}_{3}{ }^{-}$concentration in the $\mathrm{AG}$ $122 ®$ cultivar. Thus, the AG $122 \AA$ cultivar has a stronger tendency to perform $\mathrm{N}$ metabolism in the shoots.

Small differences in the $\mathrm{NH}_{4}^{+}-\mathrm{N}$ levels were observed between genotypes. However, the values were too low to correspond to any biological effect (Figure 3). The uptake of $\mathrm{NO}_{3}{ }^{-}$may follow different routes. $\mathrm{NO}_{3}^{-}$may be assimilated or stored in vacuoles in the root or transported to the shoot and assimilated or stored in the vacuoles of this structure (SANTOS et al., 2011). Plants may differ in the ability to metabolize $\mathrm{NO}_{3}^{-}$in the root or shoot, as observed in the AG $122 \AA$ cultivar and the Sol da Manhã and Eldorado varieties (TAIZ; ZEIGER, 2004).

The amino-N and soluble sugar levels suggest that the $\mathrm{AG} 122 \AA$ cultivar had a stronger tendency to perform $\mathrm{NO}_{3}^{-}$metabolism in the shoots, whereas the Sol da Manhã and Eldorado varieties had a stronger tendency to perform $\mathrm{NO}_{3}^{-}$metabolism in the roots. Of the three genotypes studied, the AG $122 ®$ cultivar showed the highest amino-N levels and, consequently, lower soluble sugar levels in the shoots (Figure 4a and c), whereas the Sol da Manhã and Eldorado varieties showed the highest amino-N and the lowest soluble sugar levels in the roots (Figure $4 b$ and $d$ ).

Soluble sugars are indicators of energy that is readily available for cellular metabolism in plants. In addition to their role as a power source, soluble sugars act as precursors of the carbon skeletons used in the synthesis of organic acids for assimilation of $\mathrm{N}$ uptake (SOUZA et al., 1999). An inverse relationship between amino-N and soluble sugars has been extensively reported in studies with various species of plants and $\mathrm{N}$ doses (BORGES et al., 2006; OLIVEIRA et al., 2011).

In general, the treatment with $10 \mu \mathrm{M}$ P supplied to the genotypes during the uptake kinetics trial did not impose a $\mathrm{P}$ deficiency on the plants. Therefore, it was not possible to observe significant effects on $\mathrm{N}$ metabolism resulting from the difference between the $\mathrm{P}$ doses. In contrast, a comparison of the genotypes clearly shows that $\mathrm{N}$ metabolism is preferentially performed in the shoots by the AG $122{ }^{\circledR}$ cultivar and in the roots by the Sol da Manhã and Eldorado varieties. 
Figure 3. $\mathrm{NO}_{3}^{-}-\mathrm{N}(\mathrm{a}, \mathrm{b})$ and $\mathrm{NH}_{4}^{+}-\mathrm{N}(\mathrm{c}, \mathrm{d})$ content in shoots and roots in the Sol da Manhã (SM) and Eldorado varieties

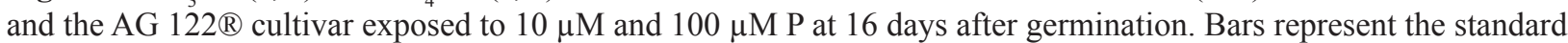
error for four replicates. Letters indicate differences between the plants in each treatment (Tukey test, $p \leq 0.05$ ).
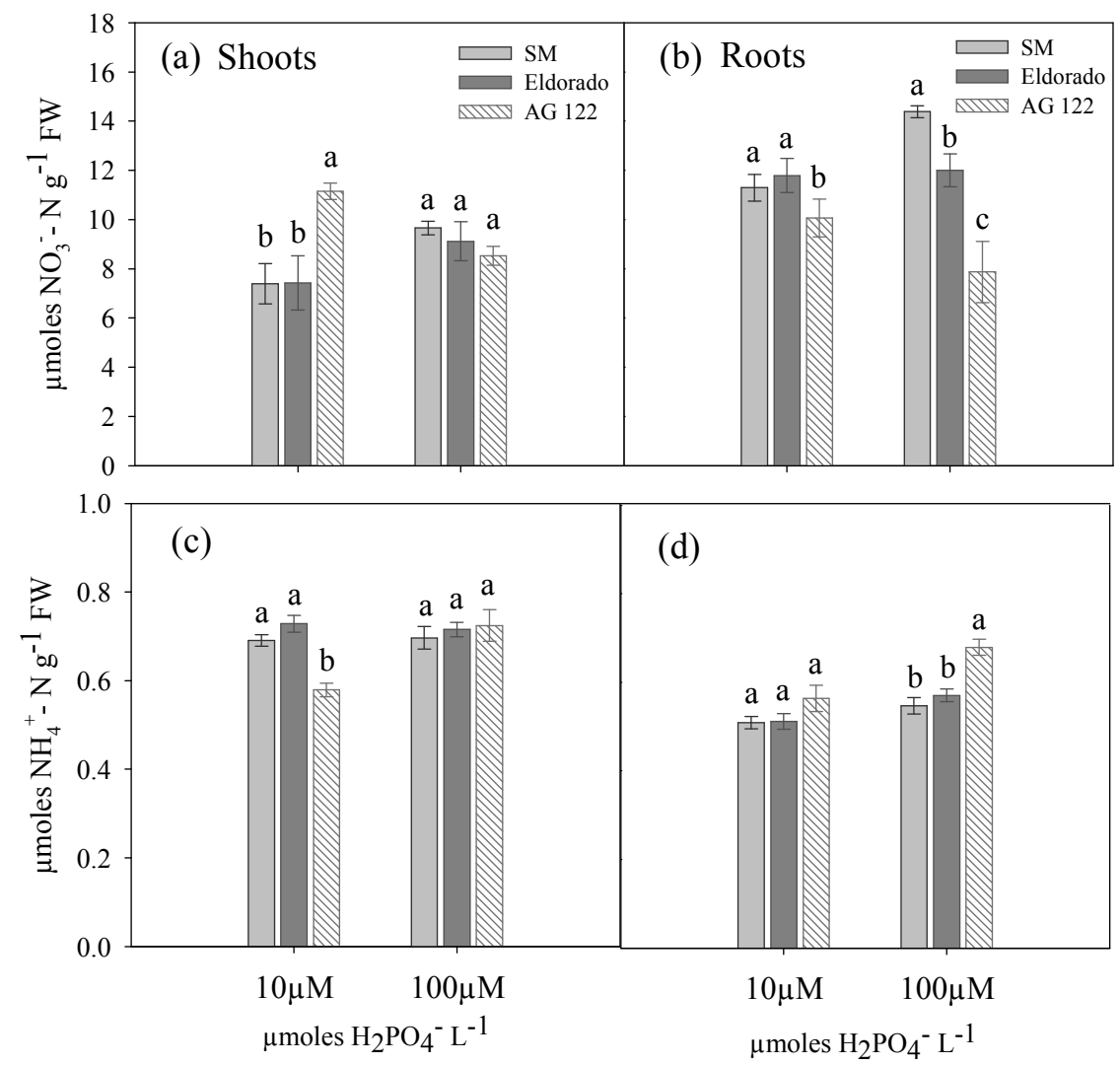

Source: Elaboration of the authors. 
Figure 4. Amino-N (a, b) and soluble sugar (c, d) content in shoots and roots in the Sol da Manhã (SM) and Eldorado varieties and the $\mathrm{AG} 122 \AA$ cultivar exposed to $10 \mu \mathrm{M}$ and $100 \mu \mathrm{M}$ P at 16 days after germination. Bars represent the standard error for four replicates. Letters indicate differences between the plants in each treatment (Tukey test, $p \leq$ $0.05)$.
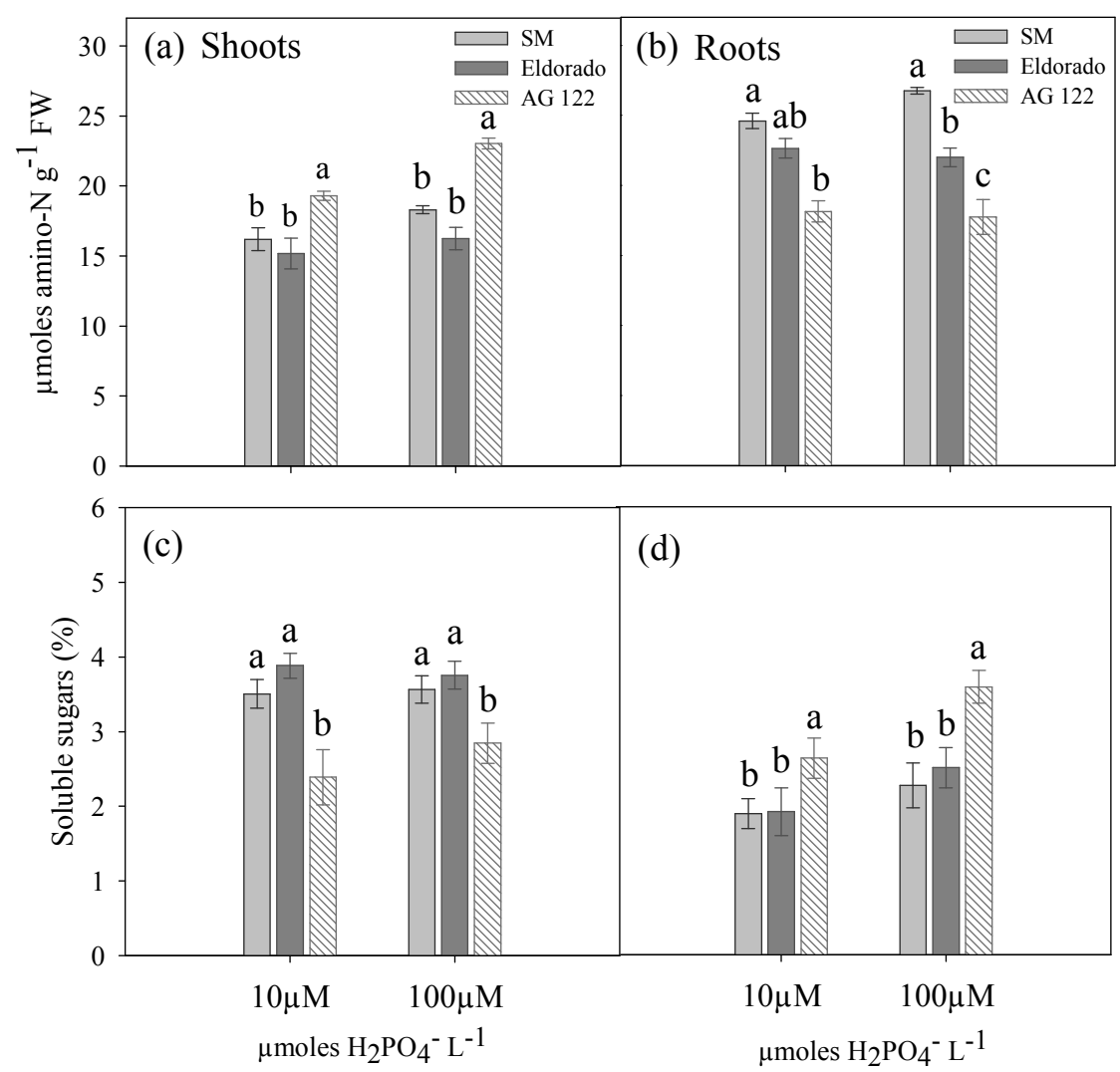

Source: Elaboration of the authors.

\section{Conclusions}

1 - Under the experimental conditions, the AG $122 ®$ cultivar showed higher uptake efficiency under the 10 and $100 \mu \mathrm{M}$ P treatments. However, the finding that the highest $\mathrm{V}_{\text {max }}$ was observed in the Sol da Manhã and Eldorado varieties is interesting in relationship to environments with a lower $\mathrm{P}$ availability.

2 - Longer periods of $\mathrm{P}$ deprivation and doses below $10 \mu \mathrm{M}$ in kinetic trials should be tested to impose a more severe $\mathrm{P}$ deficiency on the genotypes to obtain a broader characterization of the $\mathrm{P}$ uptake efficiency of these plants.

\section{Acknowledgments}

We thank the CPGA-CS (Curso de PósGraduação em Ciência do Solo) at Universidade Federal Rural do Rio de Janeiro, CNPq and FAPERJ for financial support.

\section{References}

ALVES, V. M. C.; PARENTONI, S. N.; VASCONCELLOS, C. A.; PITTA, G. V. E.; FRANÇA, C. C. M. Cinética de absorção de fósforo e crescimento do sistema radicular de genótipos de milho contrastantes para eficiência a fósforo. Revista Brasileira de Milho e Sorgo, Minas Gerais, v. 1, n. 1, p. 85-92, 2002. 
BORGES, E. A.; FERNANDES, M. S.; LOSS, A.; SILVA, E. E.; SOUZA, S. R. Acúmulo e remobilização de nitrogênio em variedades de milho. Caatinga, Mossoró, v. 19, n. 3, p. 278-286, 2006.

BRAGA, J. M.; DEFELIPO, B. V. Determinação espectrofotométrica de fósforo em extratos de solos e plantas. Revista Ceres, Viçosa, v. 113, n. 1, p. 73-85, 1974.

CARDOSO, E. J. B. N.; CARDOSO, I. M.; NOGUEIRA, M. A.; BARETTA, C. R. D. M.; PAULA, A. M. Micorrizas arbusculares na aquisição de nutrientes pelas plantas. In: SIQUEIRA, J. O.; SOUZA, F. A. de; CARDOSO, E. J. B. N.; TSAI, S. M. (Ed.). Micorrizas: 30 anos de pesquisa no Brasil. Lavras: UFLA, 2010. p. 153-214.

CATALDO, D.; HARRON, M.; SCHARADER, L. E.; YOUNGS, V. L. Rapid colorimetric determination of nitrate in plant tissue by nitration of salicylic acid. Communication in Soil Science and Plant Analysis, New York, v. 6, n. 1, p. 853-855, 1975.

CLAASSEN, N.; BARBER, S. A. A method for characterizing the relation between nutrient concentration and flux into roots of intact plants. Plant Physiology, Illinois, v. 54, n. 4, p. 564-568, 1974.

COMETTI, N.; FURLANI, P. R.; RUIZ, H. A.; FERNANDES FILHO, E. I. Soluções nutritivas: formulações e aplicações. In: FERNANDES, M. S. (Org.). Nutrição mineral de plantas. Viçosa, MG: SBCS, 2006. p. 89-144.

FAQUIN, V.; MALAVOLTA, E.; MURAOKA, T. Cinética da absorção de fosfato em soja sob influência de micorriza vesículo-arbuscular. Revista Brasileira de Ciência do Solo, Viçosa, v. 14, n. 1, p. 41-48, 1990.

FELKER, P. Microdetermination of nitrogen in seed protein extracts with the salicylate- dichloroisocyanurate color reaction. Analytical Chemistry, Washington, v. 49, n. 1, p. 1080-1080, 1977.

FERNANDES, M. S. N carriers, light and temperature influences on the free amino acid pool composition of rice plants. Turrialba, San José, v. 33, n. 3, p. 297-301, 1984.

FERNANDES, M. S.; SOUZA, S. R. Absorção de nutrientes. In: FERNANDES, M. S. (Org.). Nutrição mineral de plantas. Sociedade Brasileira de Ciência do Solo. Viçosa: Ed. SBCS, 2006. v. 1, cap. 5, p. 52-65.

HOAGLAND, D. R.; ARNON, D. I. The water-culture method for growing plants without soil. California Agricultural of Experimental Station Bull, California, v. 347, n. 1, p. 1-32, 1950.
HORN, D.; ERNANI, P. R.; SANGOI, L.; SCHWEITZER, C.; CASSOL, P. C. Parâmetros cinéticos e morfológicos da absorção de nutrientes em cultivares de milho com variabilidade genética contrastantes. Revista Brasileira de Ciência do Solo, Viçosa, v. 30, n. 1, p. 77-85, 2006.

ISRAEL, D. W.; RUFTY, T. W. Influence of phosphorus nutrition on phosphorus and nitrogen utilization efficiencies and associated physiological responses in soybean. Crop Science, Madison, v. 28, n. 6, p. 954-960, 1988.

JESCHKE, W. D.; KIRKBY, E. A.; PEUKE, A. D.; PATE, J. S.; HARTUNG, W. Effects of P deficiency on assimilation and transport of nitrate and phosphate in intact plants of castor bean (Ricinus communis L.). Journal of Experimental Botany, Lancaster, v. 48, n. 1, p. 75-91, 1997.

LIU, H.; TRIEU, A. T.; BLAYLOCK, L. A.; HARRISON, M. J. Cloning and characterization of two phosphate transporters from Medicago truncatula roots: regulation in response to phosphate and to colonization by arbuscular mycorhizal (AM) fungi. Molecular PlantMicrobe Interactions, Minnesota, v. 11, n. 1, p. 14-22, 1998.

MARSCHNER, H. Mineral nutrition of higher plants. 2. ed. Cambridge: Academic Press, 1995. 889 p.

MOREIRA, A.; GARCIA, A. G.; HEINRICHS, R.; MALAVOLTA, E. Influência do magnésio, boro e manganês na absorção de zinco por raízes destacadas de duas cultivares de arroz. Semina: Ciências Agrárias, Londrina, v. 24, n. 2, p. 213-218, jul./dez. 2003a.

MOREIRA, A.; MALAVOLTA, E.; HEINRICHS, R.; TANAKA, R. T. Influência do magnésio na absorção de manganês e zinco por raízes destacadas de soja. Pesquisa Agropecuária Brasileira, Brasília, v. 38, n. 1, p. 95-101, 2003 b.

MUCHHAL, U. S.; RAGHOTHAMA, K. G. Transcriptional regulation of plant phosphate transporters. Proceedings of the National Academy of Science, Washington, v. 96, n. 10, p. 5868-5872, 1999.

NCGA, Statistics book. Washington, D.C.: World Maize Production, 2012. Disponível em: <http://www.ncga. com/home >. Acesso em: 12 fev. 2013.

OLIVEIRA, S. A. S.; STARK, E. M. L. M.; FREITAS, J. A. E.; BERBARA, R. L.; SOUZA, S. R. Partição de nitrogênio em variedades de milho (Zea mays L.) com a aplicação foliar de microorganismos eficazes e nitrato. Revista Universidade Rural. Série Ciências da Vida, Seropédica, v. 31, n. 1, p. 57-69, 2011. 
PARENTONI, S. N.; MENDES, F. F.; GUIMARÃES, L. J. M. Melhoramento para eficiência no uso de P. In: FRITSCHE-NETO, R.; BORÉM, A. (Ed.). Melhoramento de plantas para condições de estresses abióticos. Visconde do Rio Branco: Suprema, 2011. p. 250-255.

PARENTONI, S. N.; SOUZA JÚNIOR, C. L.; CARVALHO ALVES, V. M.; GAMA, E. E. G.; COELHO, A. M.; OLIVERIRA, A. C.; GUIMARÃES, P. E. O.; GUIMARÃES, C. T.; VASCONCELOS, M. J. V.; PACHECO, C. A. P.; MEIRELLES, W. F.; MAGALHÃES, J. V.; MOREIRA GUIMARÃES, L. J.; SILVA, A. R.; MENDES, F. F.; SHAFFERT, R. E. Inheritance and breeding strategies for phosphorus efficiency in tropical maize (Zea Mays L.). Maydica, Bergamo, v. 55, n. 1, p. 1-15, 2010.

PATERNIANI, E. Métodos tradicionais de melhoramento do milho. In: BULL, L. T.; CANTARELLA, H. (Ed.). Cultura do milho: fatores que afetam a produtividade. Piracicaba: POTAFOS, 1993. p. 23-42.

PIMENTEL-GOMES, F. Curso de estatística experimental. 14. ed. Piracicaba: Editora da Universidade de São Paulo, 2000. 477 p.

RAGHOTHAMA, K. G. Phosphate acquisition. Annual Review of Plant Physiology and Plant Molecular Biology, California, v. 50, n. 1, p. 665-686, 1999.

RAGHOTHAMA, K.G. Phosphate transport and signaling. Current Opinion in Plant Biology, Amsterdam, v. 3, n. 3, p. 182-187, 2000.

RUFTY, J. R.; MACKOWN, C. T.; ISRAEL, D. W. Phosphorus stress effects on assimilation of nitrate. Plant Physiology, Illinois, v. 94, n. 1, p. 328-333, 1990.

RUIZ, H. A.; FERNANDES FILHO, E. I. Cinética: software para estimar as constantes Vmax e KM da equação de Michaelis-Menten. In: REUNIÃO BRASILEIRA DE FERTILIDADE DO SOLO E NUTRIÇÃO DE PLANTAS, 20., 1992, Piracicaba. Anais... Campinas: Fundação Cargill, 1992. p. 124-125.

SANTOS, L. A.; SANTOS, W. A.; SPERANDIO, M. V. L.; SOUZA, S. R.; FERNANDES, M. S. Nitrate uptake kinetics and metabolic parameters in two rice varieties grown in high and low nitrate. Journal of Plant Nutrition, London, v. 34, n. 7, p. 988-1002, 2011.

SCHONINGER, L. S.; GATIBONI, L. C.; ERNANI, P. R. Fertilização com fosfato natural e cinética de absorção de fósforo de soja e plantas de cobertura do cerrado. Semina: Ciências Agrárias, Londrina, v. 34, n. 1, p. 95106, 2013.
SHEN, H.; CHEN, J.; WANG, Z.; YANG, C.; SASAKI, T.; YAMAMOTO, Y.; MATSUMOTO, H.; YAN, X. Root plasma membrane $\mathrm{H}+$-ATPase is involved in the adaptation of soybean to phosphorus starvation. Journal of Experimental Botany, Lancaster, v. 57, n. 6, p. 13531362, 2006.

SOUZA, S. R.; STARK, E. M. L. M.; MAGALHÃES, J. R.; FERNANDES, M. S. Effects of supplementar $\mathrm{N}$ on the $\mathrm{N}$-assimilation enzymes, free amino-nitrogen, soluble sugars and crude protein of rice. Communications in Soil Science and Plant Analysis, New York, v. 30, n. 5-6, p. 711-724, 1999.

STEFANUTTI, R. Eficiência de absorção e utilização de fósforo e zinco por variedade arroz. 1997. Tese (Doutorado em Agronomia e Ciência do Solo) - Centro de Energia Nuclear na Agricultura. Universidade de São Paulo, Piracicaba.

TAIZ, L.; ZEIGER, E. Fisiologia vegetal. 3. ed. Porto Alegre: Artmed, 2004. 722 p.

VANCE, C. P.; UHDE-STONE, C.; ALLEN, D. L. Phosphorus acquisition and use: critical adaptations by plants for securing a nonrenewable resource. New Phytologist, Massachusetts, v. 157, n. 3, p. 423-447, 2003.

VENEKLAAS, E. J.; LAMBERS, H.; BRAGG, J.; FINNEGAN, P. M.; LOVELOCK, C. E.; PLAXTON, W. C.; PRICE, C. A.; SCHEIBLE, W.; SHANE, M. W.; WHITE, P. J.; RAVEN, J. A. Opportunities for improving phosphorus-use efficiency in crop plants. New Phytologist, Massachusetts, v. 195, n. 2, p. 306-320, 2012.

YAN, X.; LIAO, H.; CAO, A.; HE, Y. The role of root architecture in $\mathrm{P}$ acquisition efficiency of different root systems: a case study with common bean and rice. In: HORST, W.; SCHENK, M. K.; BÜRKERT, A.; CLAASSEN, H.; FLESSA, H.; FROMMER, W. B.; GOLDBACH, H. E.; OLFS, H-W.; RÖMHELD, V.; SATTELMACHER, B.; SCHMIDHALTER, U.; SCHUBERT, S.; von WIRÉN, N.; WITTENMAYER, L. (Ed.). Plant nutrition: food security and sustainability of agro-ecosystems through basic and applied research. Boston: Dordrechet Kluwer Academic Publishers, 2001. p. $590-591$.

YEMM, E. W.; COCKING, E. C. The determination of amino-acid with ninhydrin. Analytical Biochemistry, Philadelphia, v. 80, n. 1, p. 209-213, 1955.

YEMM, E. W.; WILLIS, A. I. The estimation of carbohydrates in plant extracts by anthrone. Biochemical Journal, London, v. 57, n. 3, p. 508-514, 1957. 
